\title{
Technological transitions as evolutionary reconfiguration processes: a multi-level perspective and a case-study
}

\author{
Frank W. Geels* \\ Centre for Studies of Science, Technology and Society, University of Twente, TWRC-D-311, P.O. Box 217, \\ 7500 AE Enschede, The Netherlands
}

Received 24 August 2001; received in revised form 16 October 2001; accepted 12 December 2001

\begin{abstract}
This paper addresses the question of how technological transitions (TT) come about? Are there particular patterns and mechanisms in transition processes? TT are defined as major, long-term technological changes in the way societal functions are fulfilled. TT do not only involve changes in technology, but also changes in user practices, regulation, industrial networks, infrastructure, and symbolic meaning or culture. This paper practices 'appreciative theory' [R.R. Nelson, S.G. Winter, An Evolutionary Theory of Economic Change, Bellknap Press, Cambridge, MA, 1982] and brings together insights from evolutionary economics and technology studies. This results in a multi-level perspective on TT where two views of the evolution are combined: (i) evolution as a process of variation, selection and retention, (ii) evolution as a process of unfolding and reconfiguration. The perspective is empirically illustrated with a qualitative longitudinal case-study, the transition from sailing ships to steamships, 1780-1900. Three particular mechanisms in TT are described: niche-cumulation, technological add-on and hybridisation, riding along with market growth.
\end{abstract}

() 2002 Elsevier Science B.V. All rights reserved.

Keywords: Technological transitions; Regime shifts; Evolutionary theory; Multi-level analysis; Sailing ships and steamships

\section{Introduction}

Technological Transitions (TT) are defined as major technological transformations in the way societal functions such as transportation, communication, housing, feeding, are fulfilled. TT do not only involve technological changes, but also changes in elements such as user practices, regulation, industrial networks, infrastructure, and symbolic meaning. An example is the transition in offices from punched card technology and small office technology to digital computers, 1930-1960 (Van den Ende and Kemp, 1999).

* Tel.: +31-53-489-341; fax: 31-53-489-4775.

E-mail address: f.w.geels@wmw.utwente.nl (F.W. Geels).
This paper addresses the following questions: How do TT come about? Are there particular patterns and mechanisms in transition processes? My analysis of TT is based on a particular perspective on technology, stemming from sociology of technology. In this perspective technology, of itself, has no power, does nothing. Only in association with human agency, social structures and organisations does technology fulfil functions. In this respect, Hughes (1987) coined the useful metaphor of a 'seamless web' in which physical artefacts, organisations, natural resources, scientific elements, legislative artefacts are combined in order to achieve functionalities. Rip and Kemp (1998) analyse technology as 'configurations that work'. While the term 'configurations' refers to the alignment between a heterogeneous set of elements, the addition 


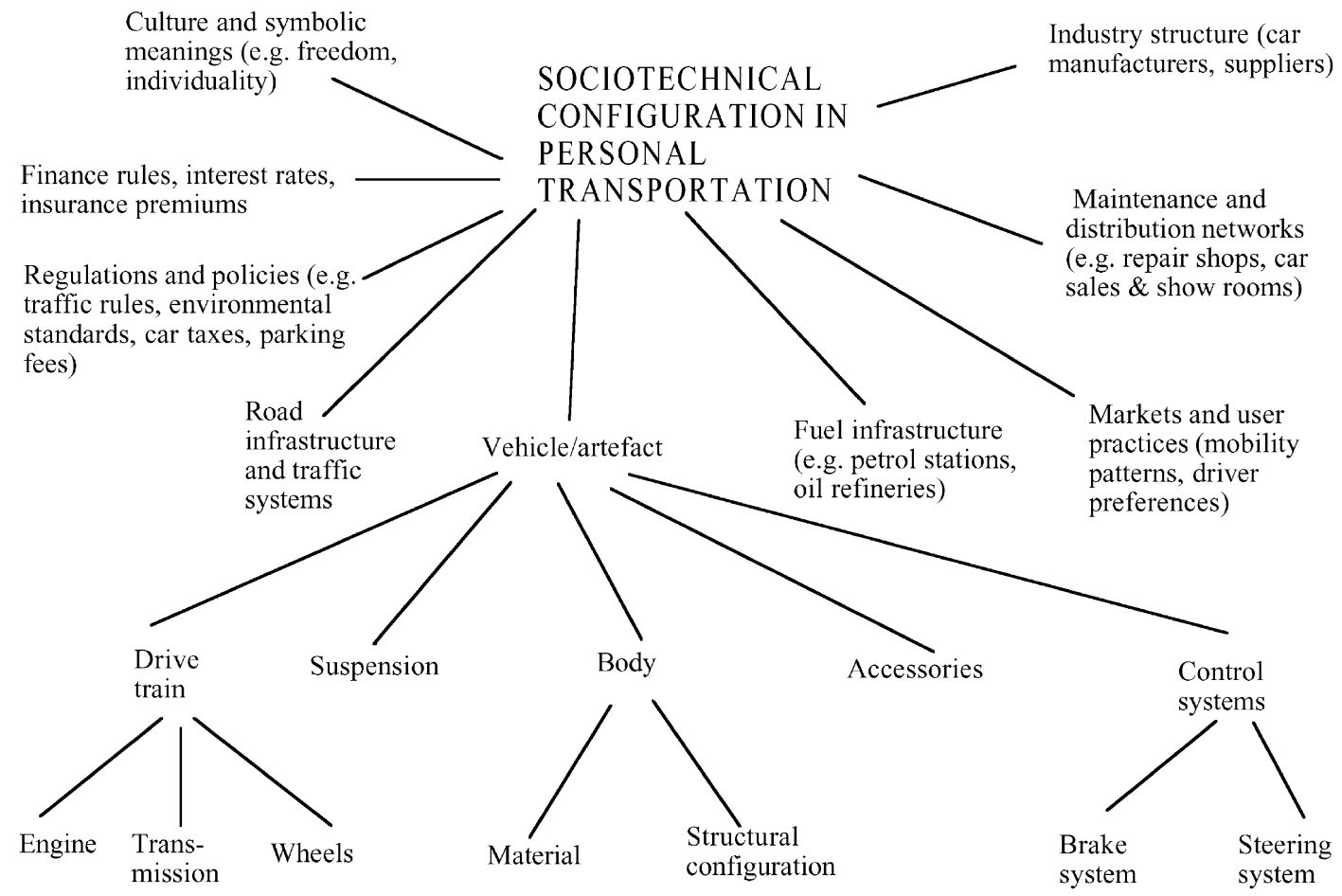

Fig. 1. Elements from the sociotechnical configuration in transportation.

'that work' indicates that the configuration fulfils a function. Configurations that work cannot easily be bounded from the rest of society in a simple and obvious way. Things and skills are part of routines, of patterns of behaviour, of organisations. They work only because they are embedded. Societal functions are fulfilled by sociotechnical configurations. Fig. 1 portrays the modern sociotechnical configuration for land-based personal transportation. The transportation function is fulfilled, because a heterogeneous set of elements is linked together.

In this conceptualisation, TT consist of a change from one sociotechnical configuration to another, involving substitution of technology, as well as changes in other elements. Such reconfiguration processes do not occur easily, because the elements in a sociotechnical configuration are linked and aligned to each other. Radically new technologies have a hard time to break through, because regulations, infrastructure, user practices, maintenance networks are aligned to the existing technology. New technologies often face a mis-match with the established socio-institutional framework (Freeman and Perez, 1988). But socio-technical configurations rarely remain 'closed' for good. Previously achieved closure can be undone. The question then becomes how we can understand inertia, and how it is overcome. Before addressing this question I will position my paper in the literature, particularly evolutionary economics and technology studies.

Within evolutionary economics, there are two views on the process of technological evolution. ${ }^{1}$ In the first view, evolution is a process of variation, selection and retention. In Section 2, I build upon this view by using Nelson and Winter's concept of 'technological regimes' to understand inertia of established technologies. In the second view, evolution is a process of unfolding, creating 'new combinations' (Schumpeter, 1934 , p. 66), resulting in paths and trajectories. While there are sophisticated debates in evolutionary economics about 'variation' (e.g. learning within firms,

\footnotetext{
${ }^{1}$ With thanks to Stan Metcalfe for pointing this out during a session at the DRUID conference.
} 
organisational routines, knowledge management), 'selection' is taken somewhat for granted. Markets are simply assumed to be 'out there'. For radically new technologies, however, there are no established markets and no fixed preferences. Radically new technologies, markets, and user preferences co-evolve. Furthermore, selection is more than adoption. User also have to integrate new technologies in their practices, organisations and routines, something which involves learning, adjustments and 'domestication' (Lie and Sørensen, 1996). Another critique is that the selection environment is wider than users and markets. Policies and institutions also play a role, as well as infrastructures, cultural discourse or maintenance networks. Although Nelson $(1994,1995)$ has done some work on such wider co-evolution processes, the topic is under-exposed in evolutionary economics. With regard to evolutionary economics, this paper explores two new things. First, a multi-level perspective is described to combine both views of evolution. Second, I complement the focus on 'variations' with attention for the wider selection environment, using the concept of socio-technical configurations.

In technology studies, the idea that linkages between technical and social elements provide stability is particularly emphasised in actor-network theory (e.g. Latour, 1991, 1993; Law and Callon, 1992). Sociotechnical change is described as a process of shifting assemblies of associations and substitutions, a reweaving of elements. Changes in one element in the network can trigger changes in other elements. The empirical illustrations of this process usually have a micro-focus. There has been relatively little attention in technology studies for long-term and large-scale technological developments. ${ }^{2}$ This paper addresses this gap.

\section{An integrative evolutionary multi-level perspective on technological transitions}

In this section, I briefly outline the multi-level framework, which has been described more elaborately

\footnotetext{
2 The exception, of course, is the tradition of large technical systems research (LTS). Much of this work, however, has a focus on the emergence of LTS (e.g. Hughes, 1983, 1987; Mayntz and Hughes, 1988) with little attention for the transition from one LTS to another (only to some extent in Summerton, 1994).
}

elsewhere (Kemp, 1994; Schot et al., 1994; Rip and Kemp, 1998; Kemp et al., 1998; Van den Ende and Kemp, 1999; Rip, 2000; Geels and Kemp, 2000; Kemp et al., 2001). The multi-level perspective aims to integrate findings from different literatures as an 'appreciative theory' (Nelson and Winter, 1982). The different levels are not ontological descriptions of reality, but analytical and heuristic concepts to understand the complex dynamics of sociotechnical change.

The stability of established sociotechnical configurations results from the linkages between heterogeneous elements. The elements and the linkages are the result of activities of social groups which (re)produce them. Road infrastructures and car regulations, for instance, are built and maintained by transportation ministries. Cultural and symbolic meanings of cars are produced in the interaction between users, media and societal groups. User practices and mobility patterns emerge from the daily use of cars by user groups. Industry structures are the outcome of mutual positioning and strategies of car manufacturers and their suppliers. The technological knowledge embodied in cars is created by car designers and engineers, while cars as artefacts are produced by car manufacturing firms. The activities of these different groups are aligned to each other and co-ordinated. To understand this co-ordination, I build upon Nelson and Winter's (1982) concept 'technological regimes'. Nelson and Winter (1982) conceptualised co-ordination as the outcome of organisational and cognitive routines. Organisations, and the actors involved, remember by doing. Such routine-based behaviour also goes for engineers, e.g. in the form of search heuristics. In so far as engineers and firms share similar routines, these form a technological regime. Technological regimes result in technological trajectories, because the community of engineers searches in the same direction. Technological regimes create stability because they guide the innovative activity towards incremental improvements along trajectories. Rip and Kemp (1998) widened the technological regime concept by defining it with the sociological category of 'rules':

"A technological regime is the rule-set or grammar embedded in a complex of engineering practices, production process technologies, product characteristics, skills and procedures, ways of handling relevant artefacts and persons, ways of defining 
problems; all of them embedded in institutions and infrastructures" (Rip and Kemp, 1998, p. 340).

While the cognitive routines of Nelson and Winter are embedded in the practices and minds of engineers, these rules are embedded more widely in the knowledge base, engineering practices, corporate governance structures, manufacturing processes and product characteristics. This widening also means that more social groups are taken on board than engineering communities. Technical trajectories are not only influenced by engineers, but also by users, policy makers, societal groups, suppliers, scientists, capital banks etc. (Fig. 2).

Because the activities of these groups are also guided by rules, I will use the term 'sociotechnical regimes' to refer to the semi-coherent set of rules carried by different social groups. By providing orientation and co-ordination to the activities of relevant actor groups, ST-regimes account for the stability of ST-configurations. This stability is of a dynamic kind, meaning that innovation still occurs but is of an incremental nature. In evolutionary terms, ST-regimes thus function as selection and retention mechanism (deep structure).

Technological trajectories are situated in a sociotechnical landscape, consisting of a set of deep structural trends. The metaphor 'landscape' is chosen because of the literal connotation of relative 'hardness' and the material context of society, e.g. the material and spatial arrangements of cities, factories, highways, and electricity infrastructures. The ST-landscape contains a set of heterogeneous factors, such as oil prices, economic growth, wars, emigration, broad political coalitions, cultural and normative values, environmental problems. The landscape is an external structure or context for interactions of actors. While regimes refer to rules that enable and constrain activities within communities, the 'ST-landscape' refers to wider technology-external factors. The context of landscape is even harder to change than that of regimes. Landscapes do change, but more slowly than regimes.

While regimes usually generate incremental innovations, radical innovations are generated in niches.

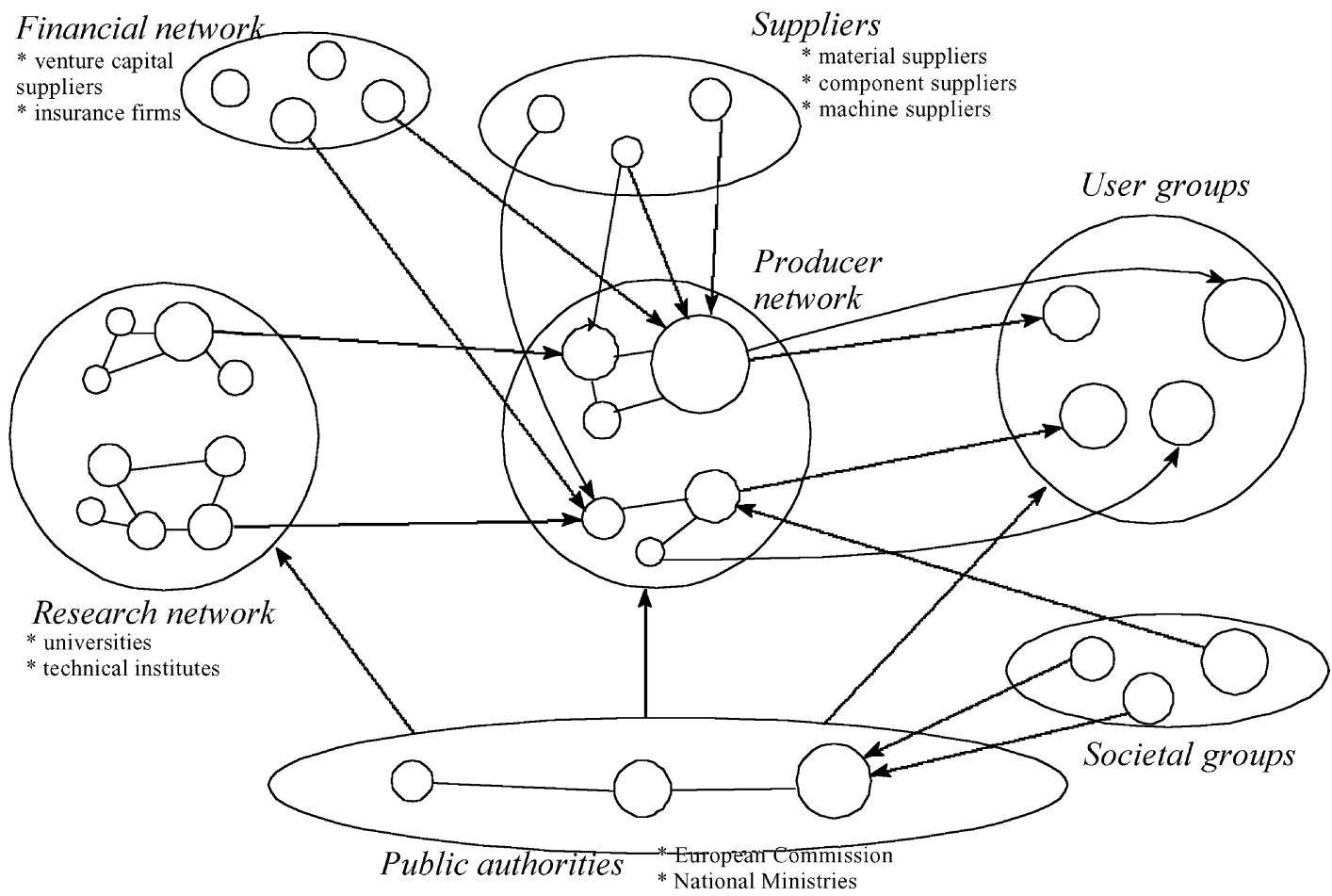

Fig. 2. The multi-actor network involved in sociotechnical regimes. 
Because these niches are protected or insulated from 'normal' market selection in the regime, they act as 'incubation rooms' for radical novelties (Schot, 1998). Radically new technologies need such protection because they usually emerge as 'hopeful monstrosities' (Mokyr, 1990). They have relatively low technical performance, are often cumbersome and expensive. Such novelties emerge in niches, which offer some protection because the selection criteria are very different from the regime. An example is the Army, which has stimulated many radical innovations in their early phases (e.g. digital computer, jet engines, radar). Niches are important, because they provide locations for learning processes, e.g. learning by doing, learning by using and learning by interacting (Rosenberg, 1976; Von Hippel, 1988; Lundvall, 1988). Niches also provide space to build the social networks which support innovations, e.g. supply chains, user-producer relationships. These internal niches processes have been analysed and described under the heading of strategic niche management (Kemp et al., 1998; Kemp et al., 2001; Hoogma, 2000).

The relation between the three concepts can be understood as a nested hierarchy or multi-level perspective (Fig. 3). The meso-level of ST-regimes accounts for stability of existing technological development and the occurrence of trajectories. The macro-level of landscape consists of slow changing external factors, providing gradients for the trajectories. The micro-level of niches accounts for the generation and development of radical innovations.
The nested character of these levels, means that regimes are embedded within landscapes and niches within regimes. Novelties emerge in niches in the context of existing regimes and landscapes with its specific problems, rules and capabilities. Novelties are produced on the basis of knowledge and capabilities and geared to the problems of existing regimes. New technologies are initially developed within the old framework (Freeman and Perez, 1988). Niches are crucial for TT, because they provide the seeds for change. Fig. 4 shows how TT start in niches. The dotted arrows indicate that the emergence of niches is strongly influenced by existing regimes and landscape.

The important point of the multi-level perspective is that the further success of a new technology is not only governed by processes within the niche, but also by developments at the level of the existing regime and the sociotechnical landscape. "It is the alignment of developments (successful processes within the niche reinforced by changes at regime level and at the level of the sociotechnical landscape) which determine if a regime shift will occur" (Kemp et al., 2001, p. 277). Changes at the landscape level, for instance, may put pressure on the regime, and create openings for new technologies. A drawback of the Rip and Kemp figure is its bias towards the novelty, and its 'innovation journey'. To counter this bias, I think more explicit attention needs to be paid to ongoing processes at the regime and landscape level. On the regime level, there are incremental processes 'down the design hierarchy’ (Clark, 1985). As a heuristic,

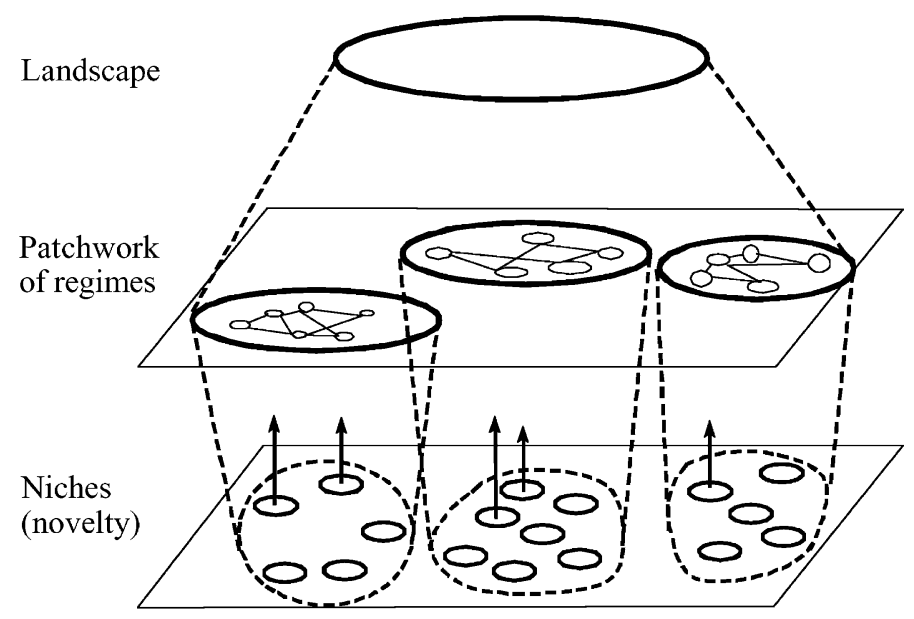

Fig. 3. Multiple levels as a nested hierarchy. 


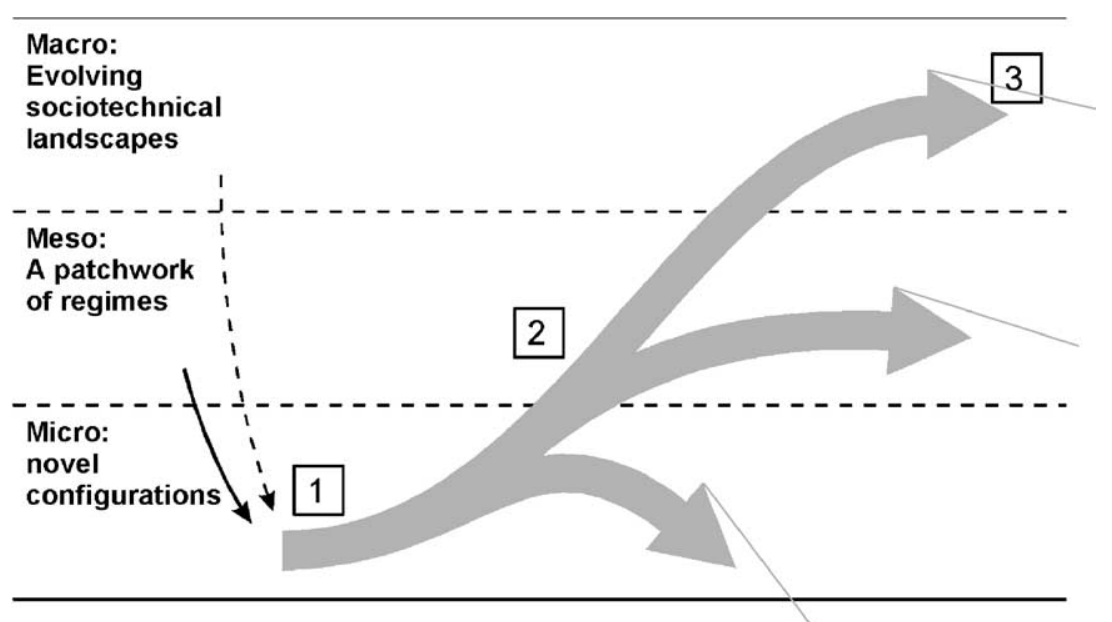

[1] Novelty, shaped by existing regime

[2] Evolves, is taken up, may modify regime

[3] Landscape is transformed

Fig. 4. The dynamics of sociotechnical change (Rip and Kemp, 1996; Kemp et al., 2001).

I have distinguished in Fig. 5 seven dimensions in the sociotechnical regime: technology, user practices and application domains (markets), symbolic meaning of technology, infrastructure, industry structure, policy and techno-scientific knowledge. The regular ongoing incremental processes are represented with relatively long arrows. Although the different dimensions are linked and co-evolve, they also have internal dynamics. This may result in 'tensions', represented in Fig. 5 with shorter diverging arrows, indicating uncertainty and differences of opinion. Tensions may lead to periods in which linkages are weakening. On the landscape level, changes usually take place slowly, e.g. cultural changes, demographic trends, broad political changes. The slowly evolving landscape developments are represented in Fig. 5 with fat long arrows. Landscape changes may put pressure on the regime. On the niche level, actors in precarious networks work on radical innovations. Because a dominant design has not yet stabilised, the efforts go in all kinds of directions, leading to variety. In Fig. 5, I represent this with small arrows going in different directions. Although radical innovations may seem promising for a while, there is no guarantee for success. Radical innovations may also gradually stabilise into a dominant design, represented in Fig. 5 with arrows growing longer and fatter.
The major point is that TT occur as the outcome of linkages between developments at multiple levels, represented with vertical dotted arrows. Radical innovations break out of the niche-level when ongoing processes at the levels of regime and landscape create a 'window of opportunity'. These windows may be created by tensions in the ST-regime or by shifts in the landscape which put pressure on the regime. Fig. 5 also shows that TT are about the linking of multiple technologies. And it shows that TT do not only involve technology and market shares but also changes on wider dimensions such as regulation, infrastructure, symbolic meaning, industrial networks (represented by the increased density of arrows). Once established, a new sociotechnical regime may contribute to changes on the landscape level.

This addition to the Rip and Kemp multi-level perspective still leaves unclear the process of breaking out of radical innovations from niche- to regime-level. How does the arrow from niche to regime come about? In Section 4, I suggest the arrow actually consists of a process of niche-cumulation. Another issue requiring further elaboration are reconfiguration processes in the regime. Before discussing both issues, I first present a case-study to illustrate the general points of the multi-level perspective. 


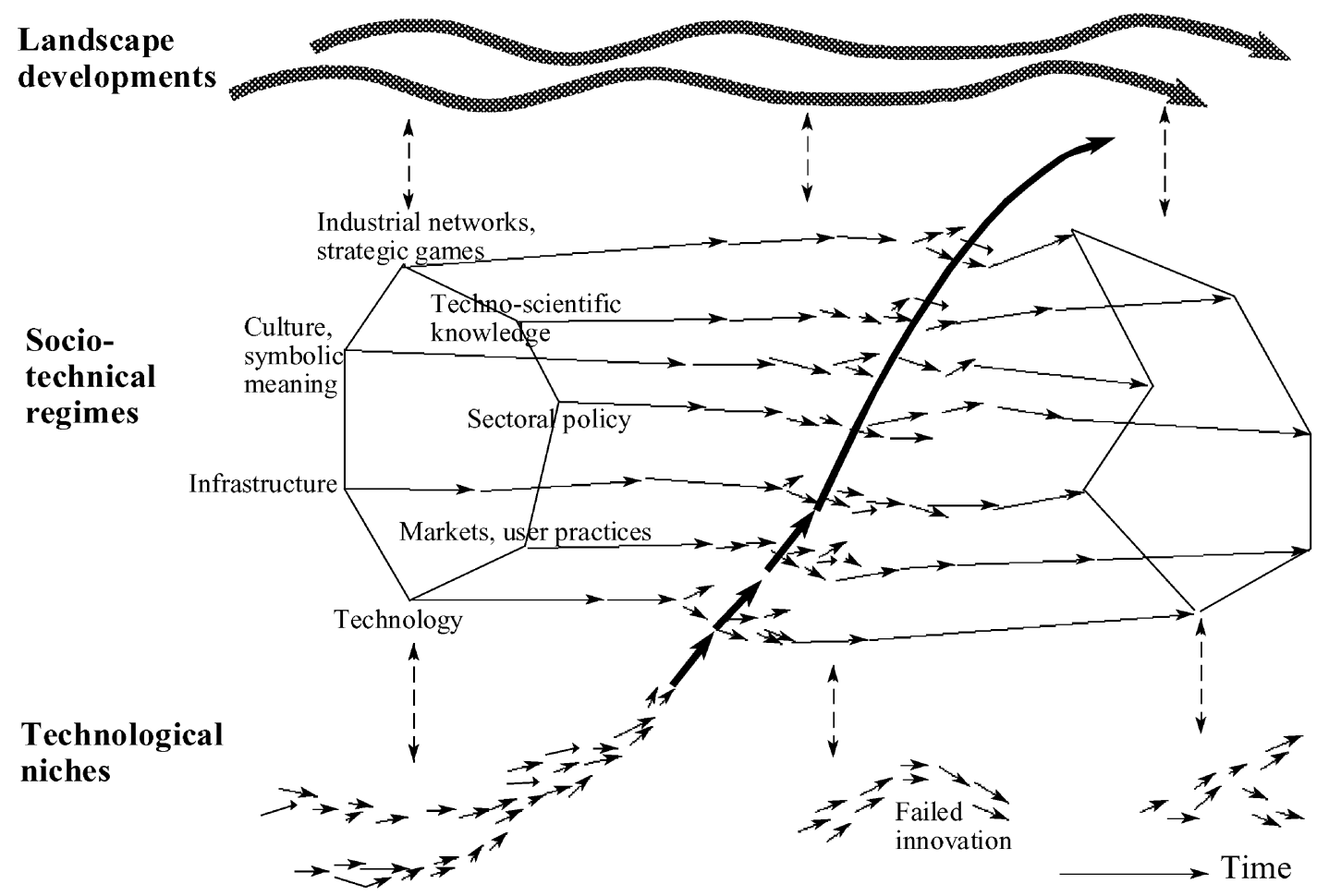

Fig. 5. A dynamic multi-level perspective on TT.

\section{Empirical case-study: from sailing ships to steamships, 1780-1900}

Traditional analyses of this transition describe it in terms of a life-cycle of steamships, a hero fighting against sailing ships (David versus Goliath). To prevent a heroic storyline, I will start the analysis with the established sailing ship regime, and show how steamships emerged within this context. I aim to tell the story in terms of complexity and reconfiguration processes. To this end, I will use a mosaic style of writing, shifting between different elements of the sociotechnical regime (markets, ship designs, insurance rules, actor groups, institutions, mail subsidies, persistent and emerging problems, management practices). I will try to show Fig. 5 in action. To understand the transition in the sociotechnical shipping regime, I will not only analyse the regime-level, but also describe relevant developments on the landscape and niche-level, and show how they linked up. The empirical description focuses on Great Britain, because this was the dominant shipping nation in the 19th century. Fig. 6 presents an aggregate representation of the transition.

\subsection{The emergence of steamships in the context of a dynamic shipping (1780-1845)}

In the late 18th century, Britain dominated the shipping regime. Countries created monopolies, which restricted colonial trade to their own ships, e.g. the British Navigation Acts. There were two types of shipping companies: chartered companies, for whom the use of ships was instrumental to colonial trade, and the captain shipowner, usually operating one ship. The latter sailed to ports without knowing in advance if there was any trade, relying on personal networks to acquire information about markets, goods and prices. If there was no trade in a foreign port, the captain either sent a letter home to ask for further instructions or sailed to another port in search for trade. Mail was a crucial means for telecommunication and co-ordination. The functioning of the 
Registration of British merchant shipping fleet (1000 net tons)

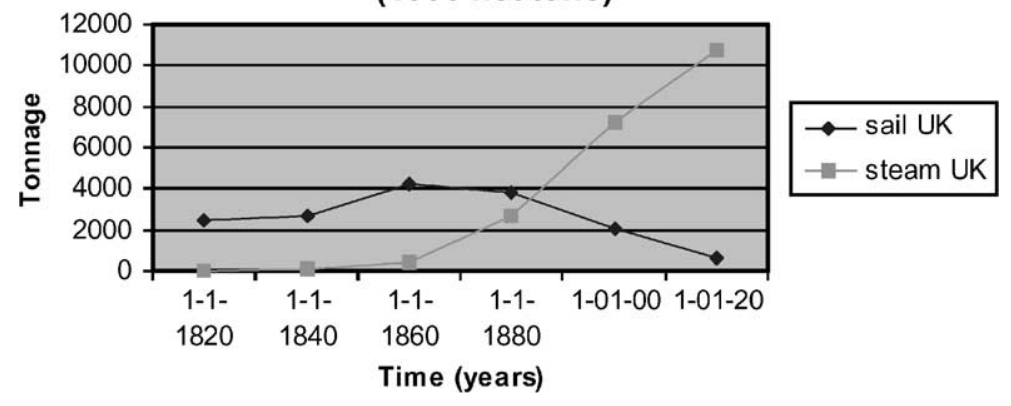

Fig. 6. British fleets of steamships and sailing ships (data are based on Ville, 1990, 68-71).

shipping regime was characterised by uncertainty and irregularity. Ships left ports when they were full and the time of arrival depended on winds and currents. The design and construction of wooden sailing ships involved skilled craftsmen, for whom intuition was more important than calculations.

British protectionism encouraged the building of a particular type of ships: wide, heavy and sluggish ships. The reason was that shipowners paid more attention to a large cargo-holding capacity than high speed. The design heuristics were not only encouraged by guaranteed markets, but also by government regulations, in particular the Tonnage Laws of 1773 which based tax on the breath of ships and not on the hold (Graham, 1956).

Design innovations in sailing ships came from American shipbuilders. After the American War of Independence (1776-1783), Britain denied American ship owners access to British and colonial markets. Hence, American traders were forced to find alternative markets. They turned their attention to the Atlantic, Mediterranean islands as well as to Mauritius and to China. In the small-volume, high-value China trade (e.g. opium, silk) American merchants became competitors of the British East India Company, and needed fast ships to evade patrols. These particular market niches stimulated the emergence of the 'Baltimore clipper', a fast but relatively small ship (Calhoun, 1973). The fast and manoeuvrable Baltimore clippers were used in the French Wars (1789-1815) to escape or get around French or British warships, and to provide shipping services to obstructed ports (Dirkzwager, 1993).
Another innovation in the late 18th century shipping regime was the emergence of new social groups: professional shipowners, shipbrokers and insurance companies. The professional shipowner offered shipping services to traders and merchants, signalling a specialisation process in which shipping emancipated itself from trade. The emergence of professional shipowners was stimulated by the French Wars (1789-1815) which pushed up freight prices as demand for ships increased. Entrepreneurial shipowners were attracted into shipping, resulting in a near doubling of the registered tonnage of the European fleet (Ville, 1990). Professional shipowning was also stimulated by the emergence of insurance companies which offered a new way of dealing with the risks of long-distance trading trips. Shipbrokers emerged to mediate between demand and supply of shipping services, i.e. between traders and professional shipowners. The mediation of the ship-broker increased the efficiency in shipping, as captains could spent less time in ports looking for cargo.

The functioning of the shipping regime was also changed by institutional innovations. In the expanding trade between America and Britain, goods were moved through increasingly denser networks of specialised middlemen, e.g. factors, financiers, brokers, advertisers, wholesalers, exporters and manufacturing agents. Innovations were made to facilitate the circulation of information, e.g. journals of prices (1795), commercial newspapers (c. 1815), mercantile libraries (1820), trade journals (1831), ship-to-shore semaphore systems (1830s), agencies for advertising (1841), and credit report books distributed by subscription (1844) 
(Beniger, 1986, pp. 200-201). New commercial institutions were also developed, e.g. formal exchanges to conduct market transactions, commercial law, and more sophisticated instruments of credit. These innovations occurred before the arrival of steamships.

Although the shipping and trading regime was innovative on several dimensions, it was plagued by persistent problems. Transportation remained unchanged on the dimension of speed. Until the 1830s, goods moved at the speed of riding horses, draft animals, and water and wind power. Teams of horses and mules powered canal boat lines, on which sustained speeds of $4 \mathrm{mph}$ proved rare. A transatlantic crossing under sail took 7 weeks plus or minus a month. Another major problem in oceanic shipping, particularly for traders and merchants, was the lack of regularity and predictability. The uncertainty about arrival and departure times made it difficult for them to plan transshipments and further distribution. Another major problem in long-distance trade was the lack of control and co-ordination, due to primitive telecommunications. Because mail was transported as slow as merchant vessels, the possibilities for feedback and communication were limited.

A major innovation, aimed at improving regularity, was fixed departure times. The Black Ball Line was the first scheduled packet service in 1818, which operated on a regular departure schedule. For a higher tariff, the packet boats carried urgent shipments, pressing mail and hurried passengers. The fast Baltimore clippers came to be widely used in this niche (Pollard and Robertson, 1979). This transportation service improved telecommunications, because mail transport was decoupled from trading vessels.

The first experiments with steamships occurred in the late 18th and early 19th century in Britain, France and America, in the niche of inland waterways. This niche emerged in the context of the 'canal-boom', a landscape development. Countries formed interconnected networks of inland waterways by constructing artificial canals and deepening rivers. The envisaged application of the steamboat experiments was a steam tug to pull ships through canals or manoeuvre them in ports. The first market niche was created in America on the Hudson River in 1807. The steamboat made an average speed of 5 miles per hour (against the flow), and was initially used for passenger services. In Britain, Henry Bell began offering commercial passenger services with steamboats in 1812. Wider applications were found in harbours, ports and estuaries, where steam tugs helped manoeuvre large sailing ships in ports. The next step was from estuaries to coastal routes and crossing small seas, for which the Irish Sea, North Sea and Channel provided natural opportunities (Broeze, 1982).

The early steamboats were small wooden vessels, using low-pressure steam engines and paddle-wheels. Because steamers carried a lot of coal, there was little capacity to transport freight. Thus, steamers could only exist commercially in places where there was large-scale passenger and mail traffic, supplemented by special low-volume high-value cargo.

There were some isolated experiments with steamships on oceans. The Savannah (320 tonnes) was the first steamship to make the Atlantic crossing in 1819. One of the earliest steamers to cross the Atlantic in a west-bound direction was a little vessel called the Rising Star, 1822 (Fig. 7). Steam engines were an auxiliary add-on to sailing ships, used at times of little winds (Dirkzwager, 1993: 73).

From the mid-1830s onward, the shipping regime changed on the market dimension as trade expanded. International and colonial trade were stimulated by the relaxation of the Navigation Laws, which in turn was related to the landscape process of political and economic liberalisation in Britain. Britain became the 'workshop of the world', selling manufactured goods, coal, textiles, ships and financial services, and importing raw cotton, metallic ores (e.g. iron, copper),

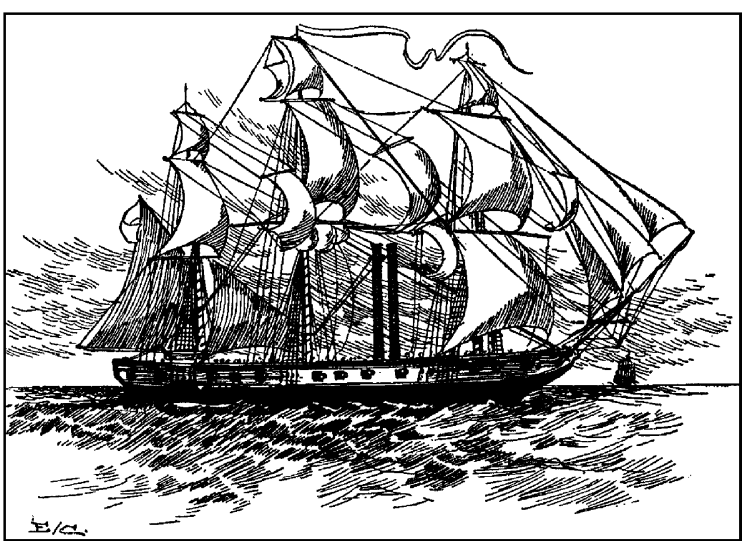

Fig. 7. The Rising Star of 1822 (Fletcher, 1910: 130). 
meat, wool, guano and rubber. The market for luxury products such as tea, coffee, sugar, expanded, just as the transportation of passengers to Australia, New Zealand and America. Baltimore clippers flourished as sailing packets in the expanding passenger markets, reaching their peak between 1825 and 1850 (Pollard and Robertson, 1979). While packet boats transported first-class passengers during the 1820 s and early 1830 s, increasing numbers of poor emigrants were transported during the 1840s. These expanding markets stimulated the further emergence of professional shipowners.

Long-distance freight shipping continued to be troubled by problems of limited control. Market information in foreign ports was not publicly available, and could not quickly be send to merchants back home (Kaukiainen, 1998). In the 1830s and 1840s, steam began to offer solutions for this problem. The railway improved overland postal connections, while steamships were making coastal traffic and the crossing of the Channel speedier and more regular. In 1838, the British government introduced mail subsidies to stimulate the use of steamships for mail transportation. Thus, the first use of oceanic steamships was aimed at improving the communication and co-ordination in the freight shipping regime.

New designs for sailing ships emerged, as the monopoly of the British East India Company was abolished in 1834. China was an attractive market because of the high value of its trade (opium, tea). High speed was valued in this market niche, because the quality of tea declined during transport. This market was quickly explored by new American ships, the opium clippers. These ships were larger than Baltimore clippers and designed for cargo, but still fast and manoeuvrable. Their main period of activity was between 1830 to 1850 , after which they were superseded by tea clippers and steamers (Pollard and Robertson, 1979).

In the $1830 \mathrm{~s}$, steamboats came to be used in small numbers in the Navy niche, for minor, additional functions such as towboats and internal mail carriage. Another use was as anti-pirate ships in the colonies (Dirkzwager, 1993). A major impulse for steamers came in 1838, when the British government issued mail subsidies on particular routes. The faster transport of mail was meant to improve communication and co-ordination within the British Empire, beneficial to both public servants and private merchants. Between 1838 and 1862 a global network of British intercontinental steam companies was created on the basis of imperial mail subsidies (Broeze, 1982). These subsidies created a protective environment for the use and development of oceanic steamships. The use of steamers introduced a new functionality in oceanic shipping: line services with fixed departure and arrival times. Because steamers were independent of winds, the regularity and reliability of services was greatly improved.

As the application domain of steamers shifted from inland waterways and coastal waters to oceans, several problems were encountered. First, the net carrying capacity of steamships was reduced, because much coal had to carried on board. This was caused by the high coal consumption of steam engines. Second, paddle-wheels did not remain in contact with the water in conditions of rough weather and large waves. This not only reduced the functioning of the paddle-wheels, but also the ship's stability and manoeuvrability. Third, the heavy weight of boilers, condensers and steam engines caused the wooden hull to bend and stretch. As steam engines and boilers grew more powerful and heavier to increase coal efficiency, this problem grew worse.

As the mail subsidies provided a guaranteed 'space' for innovations, specialised designers and shipbuilders emerged, focusing their attention on steamship developments. Because the direction of their innovative efforts was guided by the problems on the technical agenda, new technical trajectories emerged. Important technical trajectories were centred on screw propulsion, iron hulls, more efficient steam engines. The decade of the 1840s was remarkable for innovation and experimentation with these new technical elements.

Two early inventors, Ericsson and Smith, aroused great interest with five screw vessels for demonstration purposes in 1836 and 1837 (Gilfillan, 1935). Although the basic principle of screw propulsion was demonstrated, many practical problems had to be solved. In particular, the higher frequency of rotation caused the so-called vibration problem, shaking wooden ships apart. The vibration problem aggravated problems with wooden hulls, and stimulated a gradual shift towards iron hulls. Vibration also stimulated a change in the lay-out of the ship, as cabin passengers were moved from the back to 
midship. Traditionally, the stern had been the place of honour, and changing the established custom was not an easy matter (Gilfillan, 1935). Furthermore, a large variety of screw forms had to be tried out in practice.

The evolution of marine engines was that of a slow sequence of innovations. The most important way to higher coal efficiency was higher boiler pressure. In the 1830 s, the ordinary steam pressure in marine boilers averaged $5 \mathrm{psi}$ (pounds per square inch); in the $1840 \mathrm{~s} 10 \mathrm{psi}$; and in the $1850 \mathrm{~s}$ with the introduction of the tubular boiler $20 \mathrm{psi}$ (Graham, 1956). Higher boiler pressure was achieved by making boilers heavier and stronger, using stronger metals. Another search direction was boiler design. Between 1840 and 1850 tubular boilers were generally adopted, being lighter and more compact (Fletcher, 1910). Better lubricants, reducing friction between moving parts, further improved the efficiency of steam engines.

Enterprising shipbuilders began experimenting with iron ships in the 1830s. Early shipbuilders designed iron ships on the basis of rules and criteria from wooden shipbuilding practices. But these early iron ships suffered from instability, and sometimes turned upside down when they were launched (Garrat et al., 1973, 69-70). The construction of iron ships required new skills and competencies, e.g. connecting iron plates together with rivets. Iron also required different process techniques, e.g. heating, hammering, flattening, and punching. Shipbuilders used to working with wood, possessed neither the required skills nor the machines to build with iron. Hence, the construction of iron ships depended on outsiders, iron workers and boiler makers (Smith, 1937). Problems for iron ships were disturbance of the compass and rapid fouling of the hulls by marine growths. Because iron hulls disturbed the compass, iron ships were difficult to use on oceans. Hence, iron ships were first used in the niche of inland waterways. The Navy also bought some iron steamships in the late 1830s, but turned sceptical after shooting tests showed that iron hull splintered and fragmented when hit by bullets (Dirkzwager, 1993). The early scepticism was represented in formal insurance rules. High insurance premiums had to be paid for iron ships and no design rules for the construction of iron ships were issued by Lloyds until 1855 (Smith, 1937). In this context, the use of iron to build the Great Britain (1843) was a major experiment (Fig. 8). The Great Britain was a hybrid form between sailing ships and steamships. Despite the early scepticism, it was gradually found that iron had some advantages over wood. It stood fires and vibration as well as the weight of steam engines. Because of its greater strength, the hull could be thinner, even to the point of being lighter than wooden ships (Gilfillan, 1935).

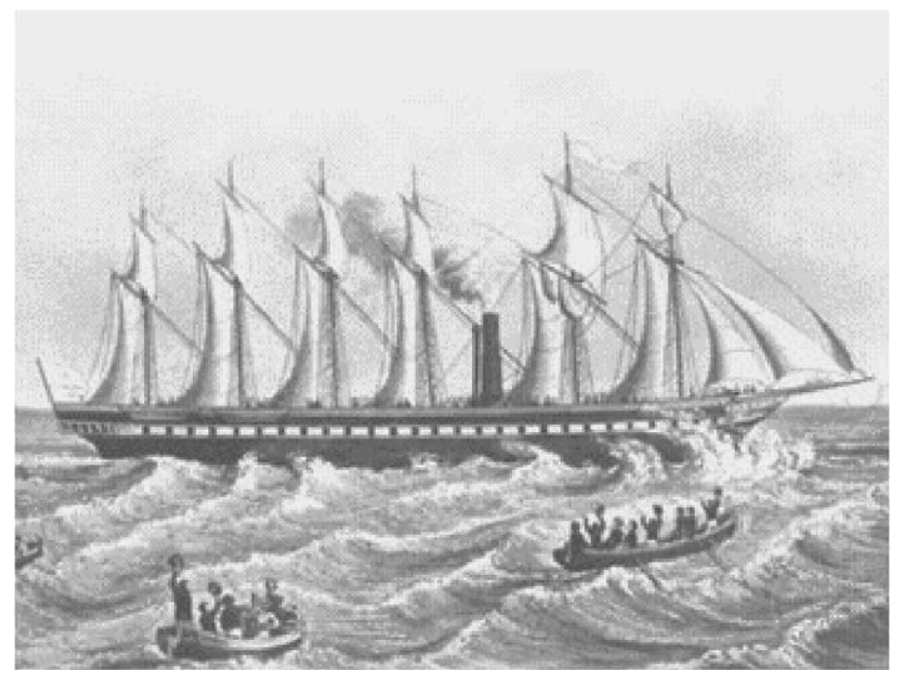

Fig. 8. The Great Britain (1843). 


\subsection{High-noon of sailing clippers and steamship take-off in passenger transport (1845-1869)}

Extending the length of opium clippers to gain speed, American shipbuilders came up in the 1840s with long cargo-carriers, known as tea clippers. After the repeal of the Navigation Acts in 1849, American clipper ships were employed on around-the-world routes. Between 1840 and 1860 American shipbuilders turned out the finest wooden sailing ships afloat. In the early 1850s, however, American shipbuilders began experiencing construction problems. As ships increased in length and approached their 'natural limit' of 275-300 feet, they met problems of longitudinal strength. While British shipbuilders in the 1850 s gradually moved to metal construction, American shipbuilders continued to use wood.

On the market dimension, the shipping regime in the 1850s and 1860s was characterised by growth. The upward market trends produced long-term optimism, indicated as 'the Golden Fifties'. Passenger transport on the North Atlantic boomed because of European emigration to Northern America. The first wave of mass emigration occurred in the late 1840s, and was related to several landscape developments, the Irish potato famine (1845-1849), European political revolutions of 1848 and the goldrush in California (1848). The landscape development of liberalisation led to the abolishment of the British Navigation Acts in 1849. In the context of liberalisation and industrialisation, freight transport expanded. Between 1840 and 1887 there was a seven-fold increase in seaborne commerce (Craig, 1980).

Stimulated by the growing opportunities and no longer protected by the Navigation Laws, Britain's pace of shipbuilding innovation quickened in the 1850s and 1860s. British Tonnage Laws were altered in 1836 to simplify methods of measurement, making tax evasions impossible. As the Tonnage Laws became compulsory in 1855 , British shipbuilders also began building clipper ships, but heavier, stronger and narrower than American clippers. Because long ships met problems of longitudinal strength, British shipbuilders gradually shifted from wood to iron as building material. Another reason was the increasing scarcity and rising price of timber in Britain (Harrison, 1990). In America, timber remained far cheaper than iron, stimulating American shipbuilders to stick with wood (Harley, 1973). Iron entered British shipbuilding in a gradual and stepwise process. Iron was first used, as an add-on, to strengthen the existing wooden constructions in the form of knees between the deckhouses and the ribs. As a hybrid, intermediate form, composite sailing clippers were built in the 1850 s, having an iron frame and wooden planking. In the late 1850 s and early 1860 s, ships with all-iron hulls and steel masts emerged. This was accompanied by a substantial revision in 1863 of Lloyds Rules, reducing the insurance premiums of iron ships (Harley, 1973).

The transatlantic transport of passengers provided the first major market niche for steamships. The strong growth in this market niche was caused European emigration. Rich emigrants were willing to pay extra for the speed, regularity and comfort steamships offered. Early steamship companies had little interest in poor emigrants, leaving them to sailing packets. After the mid-1850s, however, steamships quickly captured the emigrant market. While $45 \%$ of European emigrants travelled by steamer in 1863, this rose to $81 \%$ in 1866 (Maddocks, 1982).

Steamship liner companies turned into large professional companies, operating fleets of liners which ran to a regular timetable connected with railway services (Ville, 1990). The rise of professional shipowners was thus accelerated by the transition to steamships. Management practices changed as more attention had to be paid to matters such as fleet management, financial accounting, cost control, detailed budgeting, long-range planning (Sloan, 1998). New capital aspects related to steamships were not always appreciated, as accountants continued to rely on conventional financial standards and often failed to grasp the matter of steam vessel depreciation (Sloan, 1998).

Because of its profitability, the Atlantic Ocean turned into a competitive arena between liner companies. To distinguish themselves liner companies ordered ships that were ever larger, faster, safer, more luxurious and modern. The emerging innovation race, provided an incentive for further work on iron hulls, screw propulsion and better steam engines.

By the mid-1850s more iron ships were built, and shipbuilders began to rise above the experimental stage. The Navy changed its hesitant attitude towards iron after grenades were introduced in the Crimean War (1853-1856). The wider acceptance was accompanied by Lloyd's lowering of insurance premiums in 
1863. To deal with the fouling problem, anti-fouling paints were developed containing salts of mercury, lead, antimony, zinc and copper.

Screw-propulsion established itself as the dominant propulsion mode in the 1850s and 1860s. Its acceptance was accompanied by the lowering in the $1850 \mathrm{~s}$ of insurance premiums on screw ships from 4 to $1.25 \%$ (Lambert, 1999). The acceptance was stimulated by the emergence of iron hulls which could better stand the constant vibration of screw propulsion.

A promising way to increase coal efficiency were compound engines, using high-pressure steam twice. The steam from the first cylinder, where the initial pressure was great, would be passed to a second cylinder of greater bore. Compound engines had been developed for land-based, stationary applications in the early 19th century, but could not be used on oceans because injection of salt water, to condense the steam, resulted in sedimentation on the inside of the cylinder, reducing its working and creating explosion problems. In the 1850 s, surface condensers were developed to prevent this problem. The working of the compound engine was further enhanced as boiler pressure increased from $30 \mathrm{psi}$ in 1860 to $70 \mathrm{psi}$ in the mid-1870s. The compound engine was crucial for steamships on long-distance routes, as it improved coal efficiency, enabling reductions in fuel consumption of $60 \%$ (Graham, 1956).

In the 1850 s and early 1860 s the technical trajectories of screws, iron hull and compound engine were gradually linked together, resulting in a new technical steamship regime. One impressive but costly experiment was the Great Eastern, launched in 1858 (Fig. 9). The combination of steam and sail was aimed to assist the ship around the Cape. The introduction of compound engines made it possible to use steamships in particular long-distance market niches in freight shipping. In 1866, steamers with compound engines, using $40 \%$ less fuel, competed successfully in the China tea trade with sailing ships (Craig, 1980).

\subsection{Competition between steam and sail in freight and wider transformations (1869-1900)}

Passenger transportation continued to be a growth market for steamships and many new liner companies were formed in the 1870s on the Atlantic and in the Indian Ocean (Broeze, 1982). In the 1880s and 1890s,

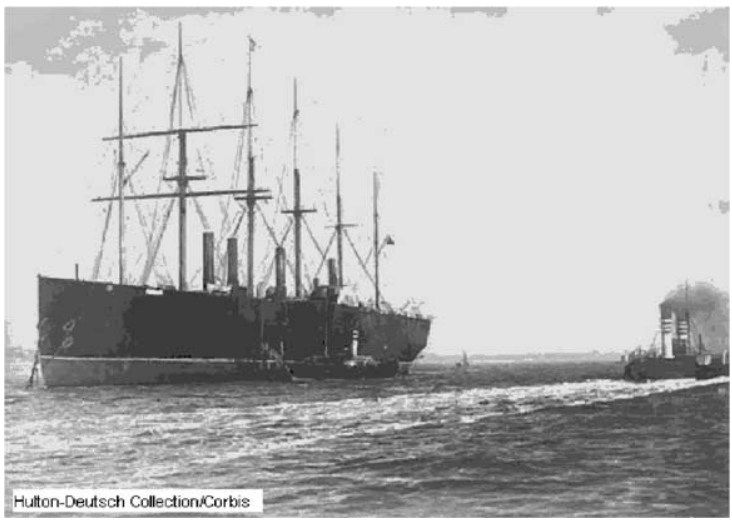

Fig. 9. The Great Eastern, 1858.

emigration to America speeded up again, providing a profitable market niche. Expansion of steamships also occurred in freight transportation. Because of the compound engine, the distance margin, where steam was competitive against sail, was raised to 3000-3500 miles by the end of the 1860s (Harley, 1988). This enabled freight steamers to be used on the North Atlantic grain trade and increasingly in the grain trades from the Black Sea. A major change in the physical landscape was the opening of the Suez Canal in 1869. The Canal not only shortened distances to the east, but also proved unsuitable for sailing ships, because of few and variable winds. Hence, the Canal gave steamships a great comparative advantage on freight routes to India and China. The new Chinese and Indian freight trades gave rise to the steamship mania (1869-1874): the percentage of steamers in the British fleet rose from $17 \%$ of total registered tonnage to $31 \%$. After 1874 , the distance margin further increased as steam engines continued their efficiency improvements. The diffusion of steamships was gradual, however, and sailing ships continued to be used well into the 20th century. There are three complementary reasons why this shift was gradual. The first reason were technical improvements, which reduced coal consumption, leading to a gradual increase of the 'distance margin' of steamships. Better quality steel and better lubricants, to improve airtight sealing, made it possible to create boilers with higher steam pressures (Gilfillan, 1935). Higher pressures increased the functioning of compound engines. Innovations such as superheaters and forced draught (which allowed 
the use of poorer quality coal) also enhanced coal efficiency. Improvements in the compound engine eventually resulted in the triple-expansion engine (1884). As fuel costs went down, steamers increasingly competed on long-distance voyages. Other costs also decreased. As steamships grew larger, relative transport costs per ton decreased. Lower coal consumption meant fewer stokers and reduced labour costs. Prices of iron shipbuilding decreased from the mid-1870s, because of better metal working machine-tools and cheaper metals. Improved port facilities and cargo handling, resulted in faster turnarounds in ports.

The second reason were 'defence strategies' by sailing ships. The first defence strategy was technological innovation in sailing ships (also called the sailing ship effect). Cargo capacity was increased by building larger sailing ships with composite hulls in the 1860 s and with iron hulls in the 1870s (Harrison, 1990). To reduce crew costs labour-saving machinery (e.g. for rigging) was introduced. With these new machines, sailing ships could be manned and navigated by about $30 \%$ the number of men (Graham, 1956). Higher speed was achieved by new hulls, longer ships and additional masts. The renewed sailing clippers were strong competition for steamships in the ocean trades of the 1870 s and 1880s. A second 'defence strategy' of sailing ships was to evade to new markets, as steamships threatened them. This strategy was made possible by the growth and diversification of world trade. Many of these new markets were bulk cargoes, consisting of raw materials, e.g. iron and coal, jute and rice, wool, nitrate fertiliser (guano) and wheat. Because low costs were a more important selection criterion in bulk markets than high speed, sailing ships continued to be used, particularly on routes with uniform and constant winds.

The third reason for the gradual diffusion of steamships were reconfiguration processes on wider dimensions of the shipping regime. A new ST-regime had to be created to facilitate wide diffusion of iron steamships, something which inevitably took time. Adaptations, adjustments and transformations occurred on the following elements. Ports and harbours were enlarged and deepened, as the size of steamships increased. Longer, wider and deeper locks were needed. A new generation of port facilities was developed tailored to the need for a rapid turnaround. Docks were fitted with modern cargo-handling and unloading gear, e.g. grabs, cranes and conveyor systems (Jarvis, 1998). All these changes required huge investments (Jackson, 1998). A world-wide infrastructure of coaling stations was created, as steamships spread to more routes. Shipbuilding was radically transformed by the shift from wooden sailing ships to iron steamship. Iron ships required very different construction skills (e.g. riveting) and process techniques (e.g. heating, hammering and punching of iron). New jobs emerged on shipyards, e.g. metal workers, electricians, millwrights, engineers. Many of the new workers needed specialised tools and machines, e.g. riveting machines and other kinds of machinery for working iron plates (Harley, 1973). The new machines often used new power-sources, e.g. steam power, hydraulic power, pneumatic power. As ships grew larger, so did the size of shipyards and the scale of operations. The huge hull components forced yard-owners to expand their yards and adopt cranes for haulage. Many shipbuilders were unable or unwilling to make these changes, and continued to build wooden ships. As a result, the centre of gravity in British shipbuilding moved north to the Clyde and the North East of England (Harrison, 1990). Another major transformation was the introduction of science and engineering. While shipbuilding had always been a craft-profession, it gradually turned into an applied science, something upon which most shipbuilders initially looked with unveiled hostility (Pollard and Robertson, 1979). Naval research institutes were created in the $1870 \mathrm{~s}$, for instance to do tests in experimental tanks to compare hull shapes. The user practice of steamships turned into large corporate and professional liner companies, requiring different management practices. With regard to fleet management the introduction of the submarine telegraph cable in the late 1860s and early 1870s had an enormous impact. It not only provided up-to-date information on prices in commodity and freight markets around the world, but also made possible much tighter and centralised control of ships (Jarvis, 1998). To control competition and minimise destructive rivalries, liner companies created a new market institution: the shipping conference. First created in 1875 for the Calcutta trade, these conferences were formal, often legally-binding agreements to restrict competition and stabilise market conditions (Sloan, 1998). 


\section{Analysis and some mechanisms in technological transitions}

I now return to the questions formulated at the end of Section 2. How does the arrow representing a breakthrough from niche- to regime-level, come about? And how do reconfiguration processes occur? I will address these questions on the basis of the case-study, but make the answers more general by referring to other examples. The general pattern by which radical innovations break out is that they follow trajectories of niche-cumulation. The step from niche to regime-level does not occur at once, but gradually, as radical innovations are used in subsequent application domains or market niches, i.e. a cumulation of niches (see also Levinthal, 1998). The cumulation trajectory for steamships is summarised in Fig. 10.

A simplification is that Fig. 10 suggests that the niches are waiting 'out there'. This is an incorrect suggestion, because many niches were created by landscape developments. Early steamboat experiments, for instance, occurred in the context of the canal-boom. And oceanic passenger transport in the 1840s was stimulated by emigration patterns which depended on
European political revolutions, Irish potato famine and Californian gold-rush. The India trade was opened up by the creation of the Suez Canal. Furthermore, the shift of a technology to a new niche is not an easy process, but involves experimentation, learning processes, adjustments and reconfigurations. Liner companies, for instance, had to learn new management practices as steamships were used in oceanic passenger transport.

A specific mechanism in the breakthrough of radical innovations is technological add-on and hybridisation. It means that new technologies in their early phase physically link up with established technologies, often to solve particular bottlenecks. Thus, old and new technologies do not immediately compete head on, but form some sort of symbiosis (see also Pistorius and Utterback, 1997). Steam engines, for example, entered sailing ships as an auxiliary device. The first oceanic steamships were actually sailing ships with additional steam engines (Fig. 7). Steamships in the 1840s were hybrid forms with both sail and steam propulsion (Fig. 8). A similar example in the transition in factories from steam engines to electric motors is that electric motors were initially placed between the

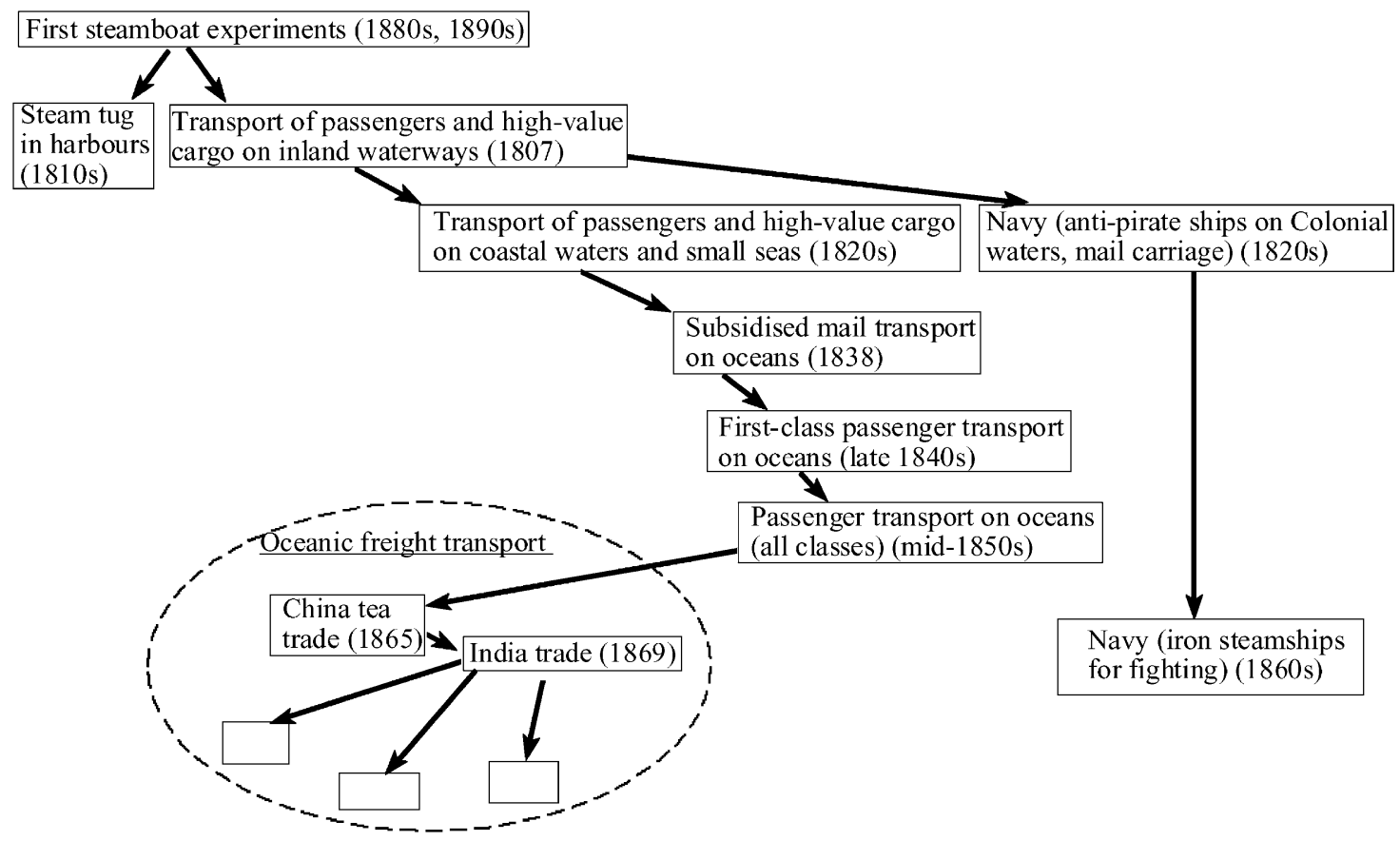

Fig. 10. Trajectory of niche-cumulation for the breakthrough of steamships. 
factory's steam engine and the line shaft to improve regularity (Devine, 1983). Another example is gas turbines in electricity production, which were first used as auxiliary device to improve the performance of the steam turbine (combined cycle power stations). As gas turbines improved, they gradually became the main component in the combined cycle, with the steam turbine taking the role of auxiliary device (Islas, 1997).

A second mechanism is that new technologies break out of niches by riding along with growth in particular markets. The take-off phase of steamships, for example, was associated with the strong growth in Atlantic passenger transportation. Similarly, electric motors rode along with the strong growth in large factories in the early 20th century. Because problems with steam engines and millwork increased with the size of factories, large factories were an appropriate niche for electric motors (Hunter and Bryant, 1991).

The answer to the second question is that TT occur not because there is a sudden shift from one regime to another, but through a stepwise process of reconfiguration. New regimes gradually grow out of old ones (Van den Ende and Kemp, 1999). What initially may appear as a revolution turns out to be the outcome of a series of adaptations and changes over time (Summerton, 1994). Cascade dynamics are important, meaning that changes in one elements of the regime triggers changes in other elements which, in turn, trigger further changes. Such reconfiguration processes take place on all dimensions of the socio-technical regime (e.g. markets, user groups and user practices, technologies, production networks, policies).

The steamship transition was not just a story of markets and technologies. The transition occurred as a shifting mosaic of elements, as changes building upon each other, and processes gradually linking up and reinforcing each other. The introduction of new elements changed the incentive structures and situation of other elements. New opportunities opened up which guided actors in different directions. TT thus appear as a process of shifting assemblies or a reweaving and reconfiguration of sociotechnical elements.

\section{Discussion and conclusions}

To answer the question how TT come about, I described a new perspective, based on insights from evo- lutionary economics and technology studies. These insights have been synthesised in a multi-level perspective consisting of three levels: technological niches, sociotechnical regimes, sociotechnical landscape. This perspective combines two views on evolution. Evolution as 'variation and selection' is encompassed by conceptualising niches as the locus where radical variety is generated, and regimes as selection and retention mechanism. Elements at the regime level are stable because they are linked together. These linkages are maintained and reproduced by the alignment and co-ordination of different actor groups. In stable situations, innovation is mainly incremental and 'down the design hierarchy'. Radical innovations, which are pioneered in niches, have a hard time to break out of the niche-level. If the regime is confronted with problems and tensions emerge, the linkages in the configuration 'loosen up'. The configuration becomes 'warm' (Callon, 1998). This creates opportunities for radical innovations to escape the niche-level and be incorporated in the ST-configuration. Evolution as 'unfolding' is included by understanding regime changes as reconfiguration processes. If new elements are introduced in the regime, they may trigger further changes if changes at the landscape level create pressure and new opportunities. Another driver for further changes is the emergence of specialised actors directing their activities towards improving and expanding the new element. Reconfigurations thus occur when developments at multiple levels link up and reinforce each other. I have shown in the case-study that steamships were initially used to improve the sailing ship regime, e.g. as steam tugs and mail steamers. Steamships broke out of the subsidised mail transport niche in the late 1840 s by linking up with the landscape development of European emigration which, in turn, was created by the Irish potato famine, European political revolutions and the Californian gold-rush. Similarly, steamships were able to enter long-distance freight shipping, because of a change in the physical landscape, the Suez Canal. Breakthroughs of innovations thus depend on processes on the level of regimes and landscapes, i.e. they are context-dependent. It is because of this aspect that the multi-level perspective is useful for analysing TT. As a further refinement within the multi-level perspective I have shown that the 'breaking out' of radical innovations can be understood as a process of niche-cumulation. 
The integration of ideas from different disciplines in the multi-level perspective is an example of 'appreciative theory' (Nelson and Winter, 1982). The multi-level perspective is not an ontological description of reality, but an analytical and heuristic framework to understand TT. The perspective forms a bridge between evolutionary economics and technology studies. Empirical analyses with the multi-level perspective can do justice to the complexity of real-world developments. This strength of the multi-level perspective is at the same time its weakness. It is still a fairly complex perspective, requiring many data, often qualitative. Furthermore, because sociotechnical regimes are a broad unit of analysis it is difficult to draw precise boundaries. Such boundary work deserves more attention in the future.

I have illustrated the conceptual perspective with a single case-study, the transition from sailing ships to steamships. This case-study has a specific drawback, because 19th century craft-based innovation has different dynamics than 20th century science-based innovation. Although I recognise this drawback, its importance is not as great as it seems. Both the conceptual perspective and the case-study have been described on an aggregated and abstract level, without saying much about (the interactions between) actors. I think the perspective and structural patterns also hold for transitions in the 20th century, as I briefly indicated with some examples in Section 4. Nevertheless, the perspective would become more robust if more case-studies were done, varied over different time-periods and sectors.

\section{Acknowledgements}

I would like to thank Adri de la Bruhèze, Bo Carlsson, Edward Constant, Jasper Deuten, Boelie Elzen, Ken Green, Luigi Orsenigo, Keith Pavitt, Arie Rip and two anonymous referees for their useful comments on previous versions of this paper. The study was supported by a grant from the Dutch research council NWO.

\section{References}

Beniger, J.R., 1986. The Control Revolution: Technological and Economic Origins of the Information Society. Harvard University Press, Cambridge, England.
Broeze, F.J.A., 1982. The international diffusion of ocean steam navigation: the myth of the retardation of Netherlands steam navigation to the East Indies. Economisch-en Sociaal-Historisch Jaarboek 45, 77-95.

Calhoun, O., 1973. The Intelligence of a People. Princeton University Press, Princeton, NJ, USA.

Callon, M. (Ed.), 1998. The Laws of the Market. Blackwell, Oxford.

Clark, K.B., 1985. The interaction of design hierarchies and market moncepts in technological evolution. Research Policy 14, 23-33.

Craig, R., 1980. The Ship: Steam Tramps and Cargo Liners, 1850-1950. Her Majesty's Stationary Office, London.

Devine Jr., W., 1983. From shafts to wires: historical perspective on electrification. Journal of Economic History 43, 347-372.

Dirkzwager, J.M., 1993. Scheepsbouw. In: Lintsen, H.W., et al. (Eds.), Geschiedenis van de Techniek in Nederland: De Wording van een Moderne Samenleving, 1800-1890. Part IV. Stichting Historie der Techniek. Walburg Pers, Zutphen, pp. 66-102.

Fletcher, R.A., 1910. Steam-Ships: The Story of Their Development to the Present Day. J.B. Lippincott, Philadelphia.

Freeman, C., Perez, C., 1988. Structural crisis of adjustment, business cycles and investment behaviour. In: Dosi, G., Freeman, C., Nelson, R., Silverberg, G., Soete, L. (Eds.), Technical Change and Economic Theory. Pinter, London, pp. 38-66.

Garrat, G.R.M., Goodman, D.C., Russel, C.A., 1973. Science and Engineering, Units 14 and 15. Open University Press, Bletchley.

Geels, F.W., Kemp, R., 2000. Transities vanuit sociotechnisch perspectief. Report for the Dutch Ministry of Environment, The Hague.

Gilfillan, S.C., 1935. Inventing the ship: a study of the inventions made in her history between floating $\log$ and rotorship. Follett, Chicago.

Graham, C., 1956. The ascendency of the sailing ship 1850-1885. Economic History Review 9, 74-88.

Harley, C.K., 1973. On the persistence of old techniques: the case of North American wooden shipbuilding. Journal of Economic History 33, 372-398.

Harley, C.K., 1988. Ocean freight rates and productivity 1740-1913: the primacy of mechanical invention reaffirmed. Journal of Economic History 48, 851-876.

Harrison, R.T., 1990. Industrial Organisation and Changing Technology in UK Shipbuilding: Historical Developments and Future Implications. Gower Publishing Company, Aldershot, Avebury.

Hoogma, R., 2000. Exploiting Technological Niches: Strategies for Experimental Introduction of Electric Vehicles. PhD thesis, Twente University Press, Enschede.

Hughes, T.P., 1983. Networks of Power, Electrification in Western Society, 1880-1930. Johns Hopkins University Press, Baltimore.

Hughes, T.P., 1987. The evolution of large technological systems. In: Bijker, W.E., Hughes, T.P., Pinch, T. (Eds.), The Social Construction of Technological Systems: New Directions in the Sociology and History of Technology. MIT Press, Cambridge, MA, pp. 51-82. 
Hunter, L.C., Bryant, L., 1991. The History of Industrial Power in the United States, 1780-1930, The Transmission of Power. Vol. 3. MIT Press, Cambridge.

Islas, J., 1997. Getting round the lock-in in electricity generating systems: the example of the gas turbine. Research Policy 26, 49-66.

Jackson, G., 1998. Ports, ships and government in the nineteenth and twentieth centuries. In: Van Royen, P.C., Fischer, L.R., Williams, D.M. (Eds.), Proceedings of the Second International Congress of Maritime History on Frutta di Mare: Evolution and revolution in the maritime world in the 19th and 20th centuries. Amsterdam/Rotterdam, The Netherlands, 5-8 June, 1996. Batavian Lion International, Amsterdam, pp. 161-176.

Jarvis, A., 1998. The nineteenth-century roots of globalization: some technological considerations. In: Starkey, D.J., Harlaftis, G. (Eds.), Global markets: the internationalization of the sea transport industries since 1850. Research in Maritime History 14, pp. 217-237.

Kaukiainen, Y., 1998. International freight markets in the 1830s and 1840s: the experience of a major Finnish shipowner. In: Starkey, D.J., Harlaftis, G. (Eds.), Global markets: the internationalization of the sea transport industries since 1850 . Research in Maritime History 14, pp. 1-27.

Kemp, R., 1994. Technology and the transition to environmental sustainability: the problem of technological regime shifts. Futures 26, 1023-1046.

Kemp, R., Schot, J.W., Hoogma, R., 1998. Regime shifts to sustainability through processes of niche formation: the approach of strategic niche management. Technology Analysis and Strategic Management 10, 175-196.

Kemp, R., Rip, A., Schot, J.W., 2001. Constructing transition paths through the management of niches. In: Garud, R., Karnoe, P. (Eds.), Path Dependence and Creation. Lawrence Erlbaum, Mahwah, NJ, pp. 269-299.

Lambert, A.D., 1999. Responding to the nineteenth century: the Royal Navy and the introduction of the screw propeller. History of Technology 21, 1-28.

Latour, B., 1991. Society is technology made durable. In Law, J., (Ed.), A Sociology of Monsters, Essays on Power, Technology and Domination. Routledge, London, pp. 103-131.

Latour, B., 1993. La clef de Berlin et autres lecons d'un amateur de sciences. Editions la Decouverte, Paris.

Law, J., Callon, M., 1992. The life and death of an aircraft: a network analysis of technical change. In: Bijker, W.E., Law, J. (Eds.), Shaping Technology/Building Society: Studies in Sociotechnical Change. MIT Press, Cambridge, MA, pp. 21-52.

Levinthal, D.A., 1998. The slow pace of rapid technological change: gradualism and punctuation in technological change. Industrial and Corporate Change 7, 217-247.

Lie, M., Sørensen, K.H. (Eds.), 1996. Making Technology Our Own: Domesticating Technology into Everyday Life. Scandinavian University Press, Oslo.

Lundvall, B.A., 1988. Innovation as an interactive process: from user-producer interaction to the national system of innovation. In: Dosi, G., Freeman, C., Nelson, R., Silverberg, G., Soete, L. (Eds.), Technical Change and Economic Theory. Pinter, London, pp. 349-369.
Maddocks, M., 1982. De Grote Oversteek. Time-Life, London.

Mayntz, R., Hughes, T.P. (Eds.), 1988. The Development of Large Technical Systems. Campus, Frankfurt.

Mokyr, J., 1990. The Lever of Riches. Oxford University Press, New York.

Nelson, R.R., 1994. The co-evolution of technology, industrial structure, and supporting institutions. Industrial and Corporate Change 3, 47-63.

Nelson, R.R., 1995. Recent evolutionary theorizing about economic change. Journal of Economic Literature 33, 48-90.

Nelson, R.R., Winter, S.G., 1982. An Evolutionary Theory of Economic Change. Bellknap Press, Cambridge, MA.

Pistorius, C.W.I., Utterback, J.M., 1997. Multi-mode interaction among technologies. Research Policy 26, 67-84.

Pollard, S., Robertson, J., 1979. The British Shipbuilding Industry, 1870-1914. Harvard University Press, Cambridge, England.

Rip, A., 2000. There's no turn like the empirical turn. In: Kroes, P., Meijers, A., Mitcham, C. (Eds.), The Empirical Turn in the Philosophy of Technology. Elsevier, Amsterdam, pp. 3-17.

Rip, A., Kemp, R., 1996. Towards a Theory of Socio-Technical Change. Mimeo University of Twente, Report prepared for Batelle Pacific Northwest Laboratories, Washington, DC. (An edited version has been published as book chapter Rip and Kemp 1998).

Rip, A., Kemp, R., 1998. Technological change. In: Rayner, S., Malone, E.L. (Eds), Human Choice and Climate Change, Vol. 2. Battelle Press, Columbus, OH, pp. 327-399.

Rosenberg, N., 1976. Perspectives on Technology. Cambridge University Press, Cambridge, England.

Schot, J.W., 1998. The usefulness of evolutionary models for explaining innovation: the case of The Netherlands in the nineteenth century. History of Technology 14, 173-200.

Schot, J.W., Hoogma, R., Elzen, B., 1994. Strategies for shifting technological systems: the case of the automobile system. Futures 26, 1060-1076.

Schumpeter, J.A., 1934. The Theory of Economic Development: An Inquiry into Profits, Capital, Credit, Interest, and the Business Cycle. Harvard University Press, Cambridge, MA.

Sloan, E.W., 1998. Private enterprise as public utility: the management of capital in two centuries of shipping business. In: Van Royen, P.C., Fischer, L.R., Williams, D.M. (Eds.), Proceedings of the Second International Congress of Maritime History on Frutta di Mare: Evolution and Revolution in the Maritime World in the 19th and 20th Centuries. Amsterdam/Rotterdam, The Netherlands, 5-8 June, 1996. Batavian Lion International, Amsterdam, pp. 89-100.

Smith, E.C., 1937. A Short History of Naval and Marine Engineering. Cambridge University Press, Cambridge.

Summerton, J. (Ed.), 1994. Changing Large Technical Systems. Westview Press, Boulder.

Van den Ende, J., Kemp, R., 1999. Technological transformations in history: how the computer regime grew out of existing computing regimes. Research Policy 28, 833-851a.

Ville, S.P., 1990. Transport and the Development of the European Economy: 1750-1918. Macmillan, Basingstoke.

Von Hippel, E., 1988. The Sources of Innovation. Oxford University Press, Oxford. 